\title{
PENINGKATAN KEKUATAN PUNTIR PRODUK BALING-BALING KAPAL BAHAN KUNINGAN DENGAN PENDEKATAN METODE TAGUCHI PADA INDUSTRI KECIL PENGECORAN NEGARA KANDANGAN KALIMANTAN SELATAN
}

\author{
M. Syafwansyah Effendi, M. Khafiz Arifin, Ahmad Hendrawan \\ Program Studi Teknik Alat Berat Jurusan Teknik Mesin \\ Politeknik Negeri Banjarmasin \\ msyafwansyah@gmail.com
}

\begin{abstract}
ABSTRAK
Peningkatan kualitas merupakan aktivitas teknik dan manajemen, melalui pengukuran karakteristik kualitas dari produk, kemudian membandingkan hasil pengukuran itu dengan spesifikasi produk yang diinginkan, serta mengambil tindakan peningkatan yang tepat apabila ditemukan perbedaan aktual dan standar.Prosedur ini juga berlaku untuk peningkatan kualitas produk baling-baling kapal kuningan maupun kuningan. Tujuan dari penelitian ini adalah untuk meningkatan kualitas kekuatan puntir produk baling-baling kapal dengan kombinasi level faktor yang berpengaruh untuk meningkatkan kekuatan puntir produk baling-baling kapal dari kuning.

Metode yang dipakai dalam penelitian ini adalah metode Metode Taguchi diperkenalkan oleh Dr. Genichi Taguchi yang merupakan metodologi baru dalam bidang teknik produksi yang bertujuan untuk memperbaiki kualitas produk dan proses serta dapat menekan biaya dan resources seminimal mungkin. Matrik Orthogonal Array yang dipakai adalah $L_{9}\left(3^{4}\right)$

Hasil Penelitian ini diharapkan dapat memberikan wawasan pengetahuan tentang proses produksi pengecoran logam untuk produk baling-baling kapal di Industri kecil Pengecoran Logam Negara Kabupaten Hulu Sungai Selatan Kalimantan Selatan khususnya atau industri pengecoran yang berbahan dasar kuningan pada umumnya. Dari data hasil perhitungan, maka dapat disimpulkan bahwa Momen Puntir tertinggi dari 9 kombinasi, 4 faktor dan 3 level yaitu 6450Nmm. Adalah percobaan ke-6 dengan kombinasinya yaitu: Temperatur peleburan: $950{ }^{\circ} \mathrm{C}$ Temperatur cetakannya $530{ }^{\circ} \mathrm{C}$, Menggunakan Cetakan kuningan (Permanen) dan menggunakan bahan tambahnya 5\%
\end{abstract}

Kata kunci : Kuningan, Metode Taguchi, Baling-baling, Kekuatan puntir

\section{PENDAHULUAN}

\section{A. Latar Belakang}

Para ahli kualitas memberikan definisi kualitas sangat beraneka ragam antar lain: kualitas adalah seberapa baik produk itu sesuai dengan spefisikasi dan kelonggaran yang disyaratkan oleh rancangan itu, kualitas dipengaruhi oleh banyak faktor, termasuk pemilihan proses pembuatan, latihan dan pengawasan angkatan kerja, jenis sistem jaminan kualitas (pengendalian proses, uji, aktifitas pemeriksaan dan sebagainya) yang digunakan seberapa jauh prosedur jaminan kualitas ini diikuti dan motivasi kerja untuk mencapat kualitas (Montgomery, 1991).

Peningkatan kualitas merupakan aktivitas teknik dan manajemen, melalui pengukuran karakteristik kualitas dari produk, kemudian membandingkan hasil pengukuran itu dengan spesifikasi produk yang diinginkan, serta mengambil tindakan peningkatan yang tepat apabila ditemukan perbedaan aktual dan standar.Prosedur ini juga berlaku untuk peningkatan kualitas produk baling-baling kapal kuningan maupun kuningan.

Produk baling-baling kapal kuningan dan kuningan merupakan produk utama industri kecil pengecoran di Negara Kabupaten Hulu Sungai Selatan Kalimantan Selatan. Bahan pembuatan baling-baling disini adalah kuningan bekas dan kuningan, melalui proses pengecoran. Pangguna produk ini adalah adalah angkutan-angkutan sungai yang banyak tersebar di Kalimantan Selatan khususnya maupun dan juga daerah-daerah lainnya di Indonesia.

Metode proses produksi baling-baling kapal di industri kecil pengecoran Negara merupakan pekerjaan turun-temurun dan sudah menghasilkan kualitas produk beragam 
terutama untuk kualitas mekanik berupa kekuatan puntir, kekuatan mulur, perpanjangan dan kekerasan permukaannya. Kualitas ini akan bisa diperbaiki/ditingkatkan maksimum dengan melakukan identifikasi faktor-faktor utama maupun kombinasinya yang sangat berpengaruh untuk peningkatan kualitas produk baling-baling kapal ini. Hal ini sangat menarik peneliti untuk melakukan riset perbaikan kualitas produksi ini dengan menerapkan suatu metode yaitu metode Taguchi

\section{B. Rumusan Masalah}

Dari Permasalahan yang ada, maka dapat dirumuskan permasalahan penelitian sebagai berikut:

1. Apakah faktor-faktor yang dominan mempengaruhi peningkatan kekua-tan puntir produk baling-baling kapal kunigan

2. Kombinasi faktor yang mana dari faktor-faktor tersebut dapat meningkatkan kekuatan puntir produk baling-baling kapal kuningan

\section{Tujuan Penelitian}

Tujuan dari penelitian ini adalah sebagai berikut :

1. Menentukan faktor-faktor yang mempengaruhi peningkatan kualitas kekuatan puntir produk baling-baling kapal

2. Menentukan kombinasi level faktor yang tepat untuk meningkatkan kekuatan puntir baling-baling kapal.

Hasil Penelitian ini diharapkan dapat memberikan wawasan pengetahuan tentang proses produksi pengecoran logam untuk produk propeller kapal di Industri Kecil Pengecoran Logam Negara Kabupaten Hulu Sungai Selatan yang dilakukan dengan pendekatan Metode Taghuci. Sehingga secara khusus dapat memberikan manfaat untuk memberikan informasi tentang kombinasi level yang tepat pada proses pengecoran balingbaling kapal sehingga dapat digunakan oleh pengrajin pengecoran logam untuk meningkatkan dan menjaga kualitas produksinya terutama kekuatan puntirnya Menambah wawasan dan pemahaman bagi peneliti dalam merancang dan menganalisa suatu percobaan dengan menggunakan Metode Taguchi

\section{Urgensi Penelitian}

Secara geografis, Kabupaten Hulu Sungai Selatan terdiri dari pegunungan yang memanjang dari arah timur ke selatan, sementara dari arah barat ke utara merupakan dataran rendah yang berawa-rawa.Daerah ini dipengaruhi iklim musim basah dan kering dengan curah hujan 178 hari.Topografi yang demikian membuat kabupaten seluas 180.494 hektar ini mengalokasikan pemanfaatan ruangnya menjadi dua bagian besar, yakni kawasan lindung dan kawasan budidaya.

Industri kecil yang punya prospek cerah dan turut mewarnai pertumbuhan perekonomian masyarakat Hulu Sungai Selatan adalah pandai besi, kipas kapal, dan kerajinan imitasi.Berbagai jenis hasil industri itu banyak ditemui di Kecamatan Daha Selatan dan Daha Utara, mulai dari kerajinan barang perhiasan imitasi sampai cor logam/kuningan.Yang terkenal dari daerah ini adalah industri cor logam yang berasal dari daur ulang bangkai pesawat terbang, khususnya di Negara. Produk yang dihasilkan antara lain baling-baling kelotok (perahu motor), peralatan pertanian, peralatan dapur, dan berbagai bentuk cenderamata dari logam. Namun, semua hasil industri kecil itu terbatas untuk memenuhi pasaran daerah setempat. Pemasaran ke luar kabupaten pun baru sebatas ke Kalimantan, Sulawesi, dan pulau Jawa. (Retno Setyowati 2001).

Seperti diketahui, bahwa sifat mekanis dari hasil coran baik aluminum maupun kuningan tidak hanya dipengaruhi oleh temperatur tuang saja, dimana waktu penuangan, temperatur cetakan dan lain sebagainya juga akan berpengaruh terhadap peningkatan kualitas mekanis baik kekuatan puntir, puntir atau kekerasan. Sehingga cukup menarik untuk mengkaji lebih dalam serta mengindentifikasi faktor-faktor yang berngaruh untuk 
meningkatkan secara maksimal kualitas baling-baling kapal kuningan dan kuningan ini sesuai dengan kondisi nyata dari industri kecil yang sedang berjalan dengan mengidentifikasi faktor-faktor yang berpengaruh pada peningkatan kualitas baling-baling dan mencari kombinasi yang tepat dari faktor-faktor tersebut untuk peningkatan kualitas tersebut.

\section{E. Ruang Lingkup dan Asumsi Penelitian}

Agar penelitian bisa terfokus dengan baik sehingga fokus pada inti permasalahan yang dibahas maka perlu diberi batasan-batasan sebagai berikut:

1. Penelitian dilakukan pada industri kecil pengrajin pengecoran logam di Negara Kabupaten Hulu Sungai Selatan

2. Penelitian dilakukan pada kondisi pengecoran logam secara tradisional

3. Penelitian yang dilakukan disini hanyalah mendapatkan kombinasi level faktor yang berpengaruh meningkatkan kekuatan puntir baling-baling kapal kuningan.

Untuk asumsi yang dikenakan agar memperjelas batasan guna pemecahan masalah adalah:

1. Bahan baku dari kuningan sekrap yang merupakan limbah proses daur ulang dan produk yang dilihat hanya propeller kapal

2. Tidak membahas masalah campuran komposisi kimia

\section{LANDASAN TEORI}

\section{A. Pengertian Puntir}

Apabila suatu batang atau poros yang salah satu ujungnya dijepit dan ujung lainnya diberi gaya kopel atau pada dua tempat disepanjang poros diberi gaya kopel yang tegak lurus sumbu batang maka batang atau poros itu dipuntir. Pembebanan seperti ini terjadi, misalnya pada poros yang harus meneruskan tenang dan pada batang torsi, penampang batang berputar. Besarnya puntiran tergantung pada gaya puntir dan pada jarak antara gaya dengan sumbu batang.

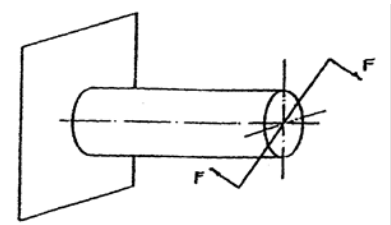

Gambar 1. Gaya Puntir

Sumber: Gere dan Timosbenko, Mekanika bahan

\section{B. Momen Puntir}

Momen puntir adalah perubahan (reaksi) yang terjadi akibat adanya gaya puntir dengan antara gaya sumbu batang. Jadi apabila suatu poros yang menerima momen puntir $M_{t}$ akan mengakibatkan kedudukan titik-titiknya bergeser.

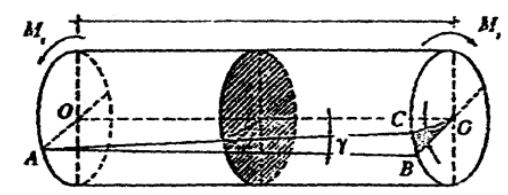

Gambar 2. Momen Puntir

Sumber: Gene dan Timoshenko, Mekanika bahan

Momen Puntir dapat dihitung dengan:

$$
\mathrm{M}_{\mathrm{p}}=\mathrm{W}_{\mathrm{p}} \cdot \tau_{t}
$$


Dimana:

$\mathrm{M}_{\mathrm{p}}=$ Momen Puntir (N.mm)

$\mathrm{W}_{\mathrm{p}}=$ Momen Tahanan Puntir $\left(\mathrm{mm}^{3}\right)$

$\tau_{t}=$ Tegangan Puntir

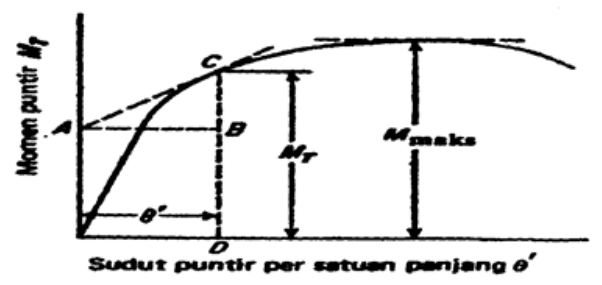

Gambar 3. Diagram Momen Puntir dan Sudut Puntir

\section{Regangan Geser $(\gamma)$}

Apabila suatu poros yang menerima momen puntir $\left(\mathrm{M}_{\mathrm{p}}\right)$ akan mengakibatkan kedudukan titik-titik bergeser, misalnya dari titik B ke titk C yang terliliatpada gambar. Jarak pergeseran titiktitik tersebutlah yang disebut dengan Regangan Geser $(\gamma)$ dalamsatuan (rad).

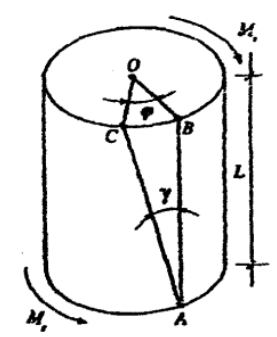

Gambar 4. Regangan Geser

Sumber: Gere dan Timoshenko, Mekanika

Regangan geser dapat dihitung :

$$
\left[\gamma=\frac{R \varphi}{L}\right]
$$

Besarnya regangan geser tersebut diperoleh dan besarnya pergeseran pada permukaan benda kerja / jari-jari persatuan panjang dan benda kerja.

Dimana:

$\gamma=$ Regangan geser (rad)

$\varphi=$ Besanan sudut puntir (derajat)

$\mathrm{L}=$ Panjang $(\mathrm{mm})$

$\mathrm{R}=\operatorname{Jari}$-jari $(\mathrm{mm})$

\section{Besarnya Sudut Puntir $\left(\varphi^{\circ}\right)$}

Sudut puntir adalah sudut yang terbentuk karena adanya puntiran. Dapat dilihat pada gambar, satu kali pemuntiran diperoleh $6^{\circ}$ sudut puntir 


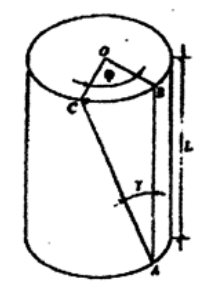

Gambar 5. Besarnya Sudut Puntir

Sumber: Gere dan Timoshenko, Mekanika

\section{E. Tegangan Puntir $\left(\tau_{t}\right)$}

Tegangan puntir adalah tegangan yang teijadi pada batang akibat adanya momen puntir yang juga merupakan tegangan geser. Tegangan puntir dapat diperoleh:

$$
\tau_{t}=M_{t} / W_{p}
$$

Dimana: $\tau_{t}=$ Tegangan puntir $\left(\mathrm{N} / \mathrm{mm}^{2}\right)$

$\boldsymbol{M}_{\boldsymbol{t}}=$ Momen puntir (N.mm)

$W_{p}=$ Momen tahanan puntir $\left(\mathrm{mm}^{3}\right)$

\section{F. Pengertian Kualitas}

Para ahli kualitas memberikan definisi kualitas sangat beraneka ragam antar lain: Kualitas adalah seberapa naik produk itu sesuai dengan spefisikasi dan kelonggaran yang disyaratkan oleh rancangan itu, kualitas kecocokan dipengaruhi oleh banyak faktor, termasuk pemilihan proses pembuatan, latihan dan pengawasan angkatan kerja, jenis sistem jaminan kualitas (pengendalian proses, uji, aktifitas pemeriksaan dan sebagainya) yang digunakan seberapa jauh prosedur jaminan kualitas ini diikuti dan motivasi kerja untuk mencapat kualitas (Montgomery, 1990).

Berdasarkan definisi tentang kualitas baik yang konvensional maupun yang lebih strategic, maka pada dasarnya kualitas mengacu pada pengertian pokok, sebagai berikut :

1. Kualitas terdiri dari sejumlah keistimewaan produk, baik keistimewaan langsung maupun keistimewaan atraktif yang mempengaruhi keinginan pelanggan dan dengan demikian memberikan kepuasan atas penggunaan produk itu.

2. Kualitas terdiri dari segala bentuk yang bebas dari kekurangan dan kerusakan (Vicent Gaspersz, 2002).

Menurut Taguchi, ada dua hal segi umum kualitas yaitu kualitas rancangan dan kualitas kecocokan. Kualitas rancangan adalah variasi tingkat kualitas yang ada pada suatu produk yang memang disengaja sedangkan kualitas kecocokan adalah sebarapa baik produk itu sesuai dengan spesifikasi pada kelonggaran yang disyaratkan oleh rancangan.

Methode Taguchi menggunakan seperangkat marik khusus yang disebut Orthogonal Array. Matrik standar ini merupakan langkah untuk menentukan jumlah percobaan minimal yang dapat memberikan informasi sebanyak mungkin semua faktor yang mempengaruhi parameter. Bagian terpenting dari metode Orthogolal Array terletak pada pemilihan kombinasi level variable-variabel input untuk masing-masing percobaan

\section{G. Logam Kuningan}

Kuningan merupakan paduan tembaga dengan seng yang paling banyak digunakan karena harganya tidak mahal, mudah dibentuk dan juga mudah untuk melakukan proses permesinan. Kuningan juga memiliki ketahanan terhadap lingkungan yang korosit.

Sifat kuningan sangat bervariasi, kekuatan dan kekerasan bergantung pada paduan dan proses pekerjaan dingin. Walaupun kuningan memilki ketahanan yang tinggi terhadap korosi, ada 2 masalah utama yang harus diperhatikan. Pada paduan kuningan memiliki 
kadar seng yang sangat tinggi, maka paduan lain yang menyusun kuningan tersebut akan berkurang seiring dengan bertambahnya kadar seng.

Kuningan dengan ukuran butir yang kecil akan lebih ulet dibandingkan dengan kuningan yang memiliki ukuran butir besar. Tetapi butiran besar ini memiliki permukaan yang lebih halus dan memerlukan sedikit proses pemolesan. Campuran besi pada kuningan akan memperkecil butiran dan memudahkan untuk proses forging, tetapi sulit untuk melakukan proses permesinan. Penambahan sedikit kadar silikon akan meningkatkan kekuatan, tetapi kadar silikon tinggi akan mengakibatkan kegetasan, dan menyebabkan reaksi dengan oksigen. Peningkatan nikel akan meningkatkan ketangguhan dan kekuatan logam.

Surdia (1991) menjelaskan bahwa kuningan adalah paduan antara Cuprum (Cu) dan Zinc (Zn) . Biasanya kandungan Zn sampai kira-kira 40\%. Kekuatan, kekerasan, dan keuletan paduan meningkat seiring dengan meningkatnya kadar seng. Kadar seng yang lebih dari 40\% akan menyebabkan penurunan kekuatan dan seng juga mudah mengguap pada saat dilebur.

Kuningan memiliki keunggulan kuat, tahan aus, dan tahan korosi. Akan tetapi harga kuningan jauh lebih mahal dari besi cor, baja dan aluminium. Kuningan yang mempunyai komposisi 60\% tembaga dan 40\% seng akan mempunyai kekuatan puntir $192 \mathrm{Mpa}$, kekerasan $40 \mathrm{Hb}$, titik lebur $1040{ }^{\circ} \mathrm{C}$ dan berat jenis $8570 \mathrm{Kg} / \mathrm{m}^{3}$. Kuningan ini sering digunakan pada peralatan yang membutuhkan kekuatan puntir tinggi seperti ; pembuatan peralatan kapal, roda gigi kecil, peralatan industri kimia.

Coran kuningan dipakai untuk bagian-bagian pompa, logam bantalan, bumbung, roda gidi dan sebagainya, dimana tidak dibutuhkan sifat-sifat yang begitu baik. Kuningan dengan kadar Tin 1,0-1,5\% disebut kuningan kapal (Naval Brass) mempunyai ketahanan tinggi terhadap korosi air garam.

\section{H. Perancangan Eksperemen Taguchi}

Metode Taguchi merupakan suatu metode dalam bidang engineering yang bertujuan memperbaiki kualitas produk atau proses dalam waktu yang bersamaan untuk menekan sumber daya dan loss function, sehingga diharapkan dapat dicapai target dan proses tidak sensitif terhadap faktor Noise.

Suatu teknik untuk mendefinisikan dan menyelidiki semua kondisi yang mungkin dalam suatu eksperimen yang melibatkan multiple faktor disebut desain eksperimen. Dalam hal ini desain eksperimen cukup efektif bila faktor dan level ditiap faktor yang terlibat dalam tiap percobaan relatif kecil jumlahnya, misal terdapat 2 dengan masingmasing 2 level, akan terdapat $2^{15}$ (32.768) kombinasi yang mungkin. Hal ini tentu sangat tidak efisien dalam hal waktu , biaya maupun tenaga.

Untuk mengatasi ini G.Taguchi mengusulkan suatu teknik untuk mempermudah eksperimen tanpa mengurangi efisien dari percobaan. Taguchi melakukan pendekatan dengan Fraktional Factorial Eksperimen yang standar dan konsisten sehingga meningkatkan efisiensi dari percobaan yang dilakukan. Dia Membangun beberapa Fraktional Factorial Eksperimen yang digunakan pada berbagai situasi. Pada Fraktional Factorial Eksperimen ini dipilih beberapa kondisi perlakuan untuk tetap mempertahankan prinsip orthogonal berbagai faktor dan kombinasi

\section{Tinjuan Penelitian Sebelumnya}

Özkan Kücü (2006) dalam penelitian “ Aplication of Taguchi Methode in the Optimization of dissolution of Ulexite in $\mathrm{NH}_{4} \mathrm{Cl}$ Solutions dimana tujuan penelitian untuk menentukan kondisi optimal pada proses ulexite $\mathrm{NH}_{4} \mathrm{Cl}$.

Faktor-faktor yang berpengaruh pada proses ulexite $\mathrm{NH}_{4} \mathrm{Cl}$ ini adalah temperature reaksi $\left({ }^{\circ} \mathrm{C}\right.$ ), solid to liquid ratio $\left(\mathrm{g} \cdot \mathrm{mL}^{-1}\right)$, Konsentrasi $\mathrm{NH}_{4} \mathrm{Cl}$, ukuran partikel, dan waktu reaksi beserta kombinasi dominannya. 
Metode pengolahan data menggunakan Metode Taguchi, Orthogonal array dengan $\mathrm{L}_{16}\left(5^{4}\right)$, ANOVA, Rasio S/N dilakukan pula ekperimen awal dan eksperimen konfirmasi. Pengolahan data dilaksanakan untuk mendapatkan pengaruh factor dominant terhadap rata-rata dan terhadap variabilitas.

Hasil akhir dari penelitian ini yaitu factor-faktor yang berpengaruh untuk kondisi optimal pada proses ulexite $\mathrm{NH}_{4} \mathrm{Cl}$ adalah Solid to liquid ratio, temperature reaksi, konsentrasi Amonium chloride, waktu reaksi dan ukuran. partikel. Kombinasi factor pada kondisi optimum pada penentukan nilai parameter adalah temperature reaksi $87^{\circ} \mathrm{C}$, Solid to liquid ratio 0,05 g.ML ${ }^{-1}$, waktu reaksi 18 menit, Konsentrasi Amonium chloride $4 \mathrm{M}$ dan ukuran partikel $256 \mu \mathrm{m}$.

K. Palaniradja, N. Alagumurthi, V. Soundararajan (2005) dalam researchnya "Optimization of Process Variabel in Gas Carburizing Process; A Taguchi Study with Esperimental Investagation on SAE 8620 and AISI 3310 Steel"' dimana tujuan research ini adalah untuk mendapat faktor-faktor pada optimasi peningkatan kualitas kekerasan permukaan dan kedalaman kasus pada logam SAE 8620 dan material baja AISI 3310.

Faktor-faktor yang dianggap mempengaruhi peningkatan kualitas kekerasan permukaan dan mikrostruktur logam SAE 8620 dan material baja AISI 3310 adalah Holding time, kandungan karbon, Carburizing temperature dan Quenching time.

Metode pengolahan data menggunakan metode Taguchi , Orthogonal Array $\mathrm{L}_{9}\left(3^{4}\right)$, ANOVA, Rasio S/N, Robust design methode.

Hasil akhir penelitian ini adalah indikasi kombinasi faktor yang mengoptimalkan kondisi proses adalah : Untuk kekerasan permukaan Holding time 210 menit, quenching time 30 menit, Kandungan karbon $1110-1115 \mathrm{mV}$, carborizing temperature $870-930^{\circ} \mathrm{C}$ dan untuk mikrostruktur, Holding time 195-210 menit, quenching time 30 menit, kandungan karbon, $1110-1115 \mathrm{mV}$, Carburizing temperature $870-930^{\circ} \mathrm{C}$.

\section{METODE PENELITIAN}

\section{A. Variabel Penelitian}

Variabel yang akan diteliti untuk mengoptimalkan respon secara serentak pada peningkatan kualitas kekerasan baling-baling kapal adalah :

1. Variabel respon, yaitu :

Variabel respon adalah berupa sifat mekanik kekuatan puntir merupakan salah satu yang menentukan kekuatan dari baling-baling ini terhadap efek dinamis gaya-gaya yang bekerja saat dioperasikan pada putaran tinggi.

2. Variabel bebas, yaitu :
a) Temperatur Peleburan $\left(940^{\circ} \mathrm{C}, 950^{\circ} \mathrm{C}, \& 970^{\circ} \mathrm{C}\right)$.
b) Temperatur Cetakan (dipanaskan sampai dengan $60^{\circ} \mathrm{C}, 348^{\circ} \mathrm{C} \& 530^{\circ} \mathrm{C}$.
c) Bahan Tambah (Tidak dengan bahan tambah \& Bahan tambah timah seng sebanyak (5\% \& 10\%).
d) Tinggi Ladel (Sentuh).
e) Penanganan Material (Tidak dibersihkan \& dibersihkan).
f) Ukuran Material (Ukuran besar (real) \& dipotong kecil-kecil).

\section{B. Langkah-langkah serta identifikasi data variabel serta percobaan}

\section{Identifikasi Masalah}

Tahapan ini merupakan tahap awal dimulainya suatu penelitian, yaitu dengan melakukan penelaahan terhadap objek yang diteliti guna mencari dan menentukan permasalahan yang muncul, kemudian ditetapkan metode yang sesuai untuk memecahkan masalah dalam peningkatan kualitas kekuatan puntir, kekerasan dan puntir produk baling-baling kapal industri kecil pengecoran logam Negara Kabupaten Hulu Sungai Selatan

2. Penetapan Tujuan Penelitian 
Penentuan tujuan penelitian ini sangat diperlukan sebagai acuan dasar bagi pelaksanaan penelitian secara keseluruhan. Penentuan tujuan ini dimaksudkan untuk memberikan arahan bagi peneliti agar penelitian ini nantinya akan mencapai hasil yang diharapkan dan tidak menyimpang atau meluas dari permasalahan yang dibahas

3. Studi Kepustakaan

Pada tahap studi kepustakaan dilakukan pengumpulan informasi-informasi yang berhubungan dengan penelitian yang akan dilaksanakan , baik dari buku panduan, literatur, artikel, jurnal, karya tulis maupun tulisan-tulisan lain yang berkaitan dengan permasalahan yang dibahas. Dari studi kepustakaan ini akan didapatkan teori maupun metode yang tepat untuk digunakan sebagai karangka berpikir dalam memecahkan permasalahan serta literatur mengenai objek penelitian menyangkut kualitas serta faktor-faktor yang mempengaruhi pada proses pengecoran kuningan

4. Penetapan Karakteristik Kualitas

Setelah diketahui permasalahan yang dihadapi serta dari studi-studi yang telah dilakukan diatas dapat dirumuskan karakteristik kualitas yang diterapkan dalam penelitian ini. Penetapan karakteristik kualitas yang tepat sangat diperlukan supaya hasil eksperimen dapat diterapkan dalam kondisi nyata.

Dari hasil pengamatan serta informasi yang diperoleh selama ini diketahui bahwa karakteristik kualitas yang merupakan variabel terikat dari proses produksi balingbaling kapal dengan bahan baku kuningan rongsokan ini adalah kekuatan puntir, kekerasaan dan puntir

5. Penetapan Level Faktor

Faktor-faktor utama yang berpengaruh tersebut diatas kemudian ditetapkan jumlah dan jenis levelnya. Penetapan levelnya dilakukan dengan mempertimbangkan titik-titik level yang memungkinkan munculnya nilai ekstrim namun masih dapat ditangani oleh teknologi yang ada.

6. Pemilihan Orthogonal Array

Setelah diketahui jumlah faktor yang berpengaruh beserta levelnya. Berikutnya adalah menyiapkan model desain eksperimen, dimana dalam hal ini menggunakan metode perancangan Taguchi yang menempatkan faktor-faktor beserta levelnya ke dalam Orthogonal Array. Penentuan jenis orthogonal array yang dikehendaki tergantung pada total derajat kebebasan yang dikehendaki.

7. Pelaksanaan Percobaan

Setelah dilakukan pemilihan Orthogonal Array dan penempatan faktor beserta levelnya ke dalam array, langkah selanjutnya adalah melakukan eksperimen berdasarkan Orthogonal Array tersebut.

Langkah ini terdiri dari persiapan eksperimen, mulai Persiapan peralatan ukur sampai persiapan objek yang akan diteliti, pelaksanaan eksperimen dengan memperhatikan variabel-variabel yang diteliti serta lamanya eksperemen dan pengambilan data eksperemen. Dari eksperimen ini akan ditempatkan semua data-data informasi yang diperlukan untuk langkah selanjutnya pengolahan data.

\section{Pengolahan Data Eksperimen}

Pemilihan Orthogonal Array berdasarkan pengamatan yang diambil melalui pemilihan faktor kualitas dan level yang sering mempengaruhi kekuatan puntir, maka Orthogonal Array yang dipakai adalah : $\mathrm{L}_{9}\left(3^{4}\right)$ (Belavendram, N. :90)

Keterangan :

$\mathrm{L}=$ Orthogonal Array

8 = Jumlah percobaan kombinasi

2 = Jumlah level yang digunakan

7 = Jumlah Faktor yang digunakan 
Tabel 1 Tabel Matrik Orthogonal Array L9$_{9}\left(3^{4}\right)$

\begin{tabular}{|c|c|c|c|c|c|c|c|}
\hline \multirow[t]{2}{*}{ No } & \multicolumn{4}{|c|}{ Faktor Kualitas dan Level } & Mp maks & Mp maks & Rata-Rata \\
\hline & A & B & $\mathrm{C}$ & $\mathrm{D}$ & Percobaan 1 & Percobaan 2 & $\Sigma$ \\
\hline 1. & 1 & 1 & 1 & 1 & & & \\
\hline 2. & 1 & 2 & 2 & 2 & & & \\
\hline 3. & 1 & 3 & 3 & 3 & & & \\
\hline 4. & 2 & 1 & 2 & 3 & & & \\
\hline 5. & 2 & 2 & 3 & 1 & & & \\
\hline 6. & 2 & 3 & 1 & 2 & & & \\
\hline 7. & 3 & 1 & 3 & 2 & & & \\
\hline 8. & 3 & 2 & 1 & 3 & & & \\
\hline 9. & 3 & 3 & 2 & 1 & & & \\
\hline
\end{tabular}

Keterangan :

\begin{tabular}{|c|l|c|c|c|}
\hline No & \multicolumn{1}{|c|}{ Faktor Kualitas } & 1 & 2 & 3 \\
\hline 1 & Temperatur peleburan & $940^{\circ}$ & $950^{\circ}$ & $970^{\circ}$ \\
\hline 2 & Temperatur cetakan & $60^{\circ}$ & $348^{\circ}$ & $530^{\circ}$ \\
\hline 3 & Jenis cetakan & Kuningan & Lilin & Besi \\
\hline 4 & Bahan tambah & $0 \%$ & $5 \%$ & $10 \%$ \\
\hline
\end{tabular}

Tabel 2 Hasil percobaan 1 Sampel 1

\begin{tabular}{|c|c|c|c|c|c|c|}
\hline $\begin{array}{l}\text { Putaran } \\
\text { (x) }\end{array}$ & $\begin{array}{c}\text { Momen } \\
\text { Puntir } \\
\text { Mp } \\
\text { (N.mm) }\end{array}$ & $\begin{array}{c}\text { Sudut } \\
\text { Puntir( } \\
\varphi) \\
\text { (Derajat/ } \\
\text { mm) }\end{array}$ & $\begin{array}{c}\text { Tegangan } \\
\text { Puntir }(\tau t) \\
\left(\mathrm{N} / \mathrm{mm}^{2}\right)\end{array}$ & $\begin{array}{c}\text { Regangan } \\
\text { Puntir }(\gamma) \\
\text { (derajat) }\end{array}$ & $\begin{array}{l}\text { Modulus } \\
\text { Geser(G) } \\
\left(\mathrm{N} / \mathrm{mm}^{2}\right)\end{array}$ & $\begin{array}{c}\text { Modulus } \\
\text { Elastisitas( } \\
\text { E) } \\
\left(\mathrm{N} / \mathrm{mm}^{2}\right)\end{array}$ \\
\hline 1 & 2100 & 6 & 49.53 & 0.45 & $36-41$ & $96-110$ \\
\hline 2 & 2500 & 12 & 58.97 & 0.90 & $36-41$ & $96-110$ \\
\hline 3 & 2600 & 18 & 61.33 & 1.35 & $36-41$ & 96-110 \\
\hline 4 & 2700 & 24 & 63.69 & 1.80 & $36-41$ & 96-110 \\
\hline 5 & 2900 & 30 & 68.41 & 2.25 & $36-41$ & $96-110$ \\
\hline 6 & 2800 & 36 & 66.05 & 2.70 & $36-41$ & $96-110$ \\
\hline 7 & 2900 & 42 & 68.41 & 3.15 & $36-41$ & $96-110$ \\
\hline 8 & 3000 & 48 & 70.77 & 3.60 & $36-41$ & $96-110$ \\
\hline 9 & 3100 & 54 & 73.13 & 4.05 & $36-41$ & $96-110$ \\
\hline 10 & 3200 & 60 & 75.48 & 4.50 & $36-41$ & $96-110$ \\
\hline 11 & 3200 & 66 & 75.48 & 4.95 & $36-41$ & $96-110$ \\
\hline 12 & 3300 & 72 & 77.84 & 5.40 & $36-41$ & $96-110$ \\
\hline 13 & 3400 & 78 & 80.20 & 5.85 & $36-41$ & 96-110 \\
\hline 14 & 3500 & 84 & 82.56 & 6.30 & $36-41$ & $96-110$ \\
\hline 15 & 3600 & 90 & 84.92 & 6.75 & $36-41$ & $96-110$ \\
\hline 16 & 3600 & 96 & 84.92 & 7.20 & $36-41$ & $96-110$ \\
\hline 17 & 3700 & 102 & 87.28 & 7.65 & $36-41$ & $96-110$ \\
\hline 18 & 3900 & 108 & 92.00 & 8.10 & $36-41$ & $96-110$ \\
\hline 19 & 3900 & 114 & 92.00 & 8.55 & $36-41$ & $96-110$ \\
\hline 20 & 4000 & 120 & 94.36 & 9.00 & $36-41$ & $96-110$ \\
\hline
\end{tabular}




\begin{tabular}{|c|c|c|c|c|c|c|}
\hline 21 & 4100 & 126 & 96.72 & 9.45 & $36-41$ & $96-110$ \\
\hline 22 & 4300 & 132 & 101.43 & 9.90 & $36-41$ & $96-110$ \\
\hline 23 & 4200 & 138 & 99.07 & 10.35 & $36-41$ & $96-110$ \\
\hline 24 & 4300 & 144 & 101.43 & 14.40 & $36-41$ & $96-110$ \\
\hline 25 & 4500 & 150 & 106.15 & 11.25 & $36-41$ & $96-110$ \\
\hline 26 & 4500 & 156 & 106.15 & 11.70 & $36-41$ & $96-110$ \\
\hline 27 & 4600 & 162 & 108.51 & 12.15 & $36-41$ & $96-110$ \\
\hline 28 & 4600 & 168 & 108.51 & 12.60 & $36-41$ & $96-110$ \\
\hline 29 & 4700 & 174 & 110.87 & 13.05 & $36-41$ & $96-110$ \\
\hline 30 & 4800 & 180 & 113.23 & 13.50 & $36-41$ & $96-110$ \\
\hline 31 & 4900 & 186 & 115.59 & 13.95 & $36-41$ & $96-110$ \\
\hline 32 & 4800 & 192 & 113.23 & 14.40 & $36-41$ & $96-110$ \\
\hline
\end{tabular}

Tabel 3. Tabel Gaya Puntir

\begin{tabular}{|l|c|c|c|c|c|c|}
\hline \multirow{2}{*}{ No } & \multicolumn{3}{|c|}{ Faktor Kualitas dan Level } & Mp ( maks ) & Mp ( maks ) \\
\cline { 2 - 7 } & A & B & C & D & Percobaan 1 & Percobaan 2 \\
\hline 1. & 1 & 1 & 1 & 1 & 6200 & 5300 \\
\hline 2. & 1 & 2 & 2 & 2 & 1600 & 2000 \\
\hline 3. & 1 & 3 & 3 & 3 & 1700 & 1700 \\
\hline 4. & 2 & 1 & 2 & 3 & 4900 & 6700 \\
\hline 5. & 2 & 2 & 3 & 1 & 2100 & 4800 \\
\hline 6. & 2 & 3 & 1 & 2 & 6600 & 6300 \\
\hline 7. & 3 & 1 & 3 & 2 & 6400 & 5200 \\
\hline 8. & 3 & 2 & 1 & 3 & 3300 & 5100 \\
\hline 9. & 3 & 3 & 2 & 1 & 5000 & 4500 \\
\hline
\end{tabular}

\section{ANALISA DAN PEMBAHASAN MASALAH}

A. Bahan Penganalisaan

Jenis bahan yang kami gunakan dalam penganalisaan ini adalah kuningan rongsokan dan juga timah seng bekas sebagai bahan tambah pada proses pengecoran yang berguna untuk meningkatkan kekuatan puntir dari kuningan rongsokan tersebut.

B. Data Pengujian dan Pembahasan

Berdasarkan data dari beberapa percobaan sebelumnya yang telah didapatkan, maka kita dapat menghitung beberapa harga penting lainnya dari test piece yang diuji, antara lain :

\section{Contoh Perhitungan Data Sampel 1}

$\mathrm{Mp} \quad=2,1 \mathrm{~N} \cdot \mathrm{m} \approx 2100$ N.mm

Dicari Tegangan puntir $\tau_{\mathrm{t}}\left(\mathrm{N} / \mathrm{mm}^{2}\right)$

$$
\begin{gathered}
\tau_{t}=\frac{M p}{W p} \\
W p=\frac{I p}{R} \\
=\frac{\frac{\pi}{32} d^{4}}{d / 2}
\end{gathered}
$$




$$
\begin{aligned}
& =\frac{\pi}{16} d^{3} \\
& =\frac{3,14}{16}(6)^{3} \\
& =42,39 \mathbf{m m}^{3}
\end{aligned}
$$

Jadi besarnya tegangan puntir adalah

$$
\begin{aligned}
\tau_{t} & =\frac{M p}{W p} \\
& =\frac{2100}{42,39}=49,53 \mathrm{~N} / \mathrm{mm}^{2}
\end{aligned}
$$

Kemudian besarnya regangan geser $(\gamma)$ yang terjadi

$$
\begin{aligned}
\gamma & =\frac{R \cdot \varphi}{L} \\
& =\frac{3 x 6}{40}=\mathbf{0 , 4 5} \mathrm{rad}
\end{aligned}
$$

dimana :

$$
\begin{aligned}
& \mathrm{Mp}=\text { momen puntir dalam }(\mathrm{N} . \mathrm{mm}) \\
& \varphi^{o}=\text { sudut puntir }(\text { Derajat } / \mathrm{mm}) \\
& \mathrm{L}=\text { Panjang }(\mathrm{mm}) \\
& \mathrm{R}=\text { Jari-jari }(\mathrm{mm}) \\
& \tau_{\mathrm{t}}=\text { Tegangan puntir }\left(\mathrm{N} / \mathrm{mm}^{2}\right) \\
& \gamma=\text { regangan geser }(\mathrm{rad}) \\
& \mathrm{W}_{\mathrm{p}}=\text { Momen tahanan puntir }\left(\mathrm{mm}^{3}\right) \\
& \mathrm{I}_{\mathrm{p}}=\text { Inersia puntir }\left(\mathrm{mm}^{4}\right)
\end{aligned}
$$

Untuk perhitungan putaran selanjutnya mengikuti cara diatas

Tabel 4. Tabel Matrik Orthogonal Array $\mathrm{L}_{9}\left(3^{4}\right)$

\begin{tabular}{|c|c|c|c|c|c|c|c|}
\hline \multirow{2}{*}{ No } & \multicolumn{4}{|c|}{ Faktor Kualitas dan } & Mp ( maks ) & Mp ( maks ) & Rata-Rata \\
\cline { 2 - 8 } & A & B & C & D & Percobaan 1 & Percobaan 2 & $\Sigma$ \\
\hline 1. & 1 & 1 & 1 & 1 & 6200 N.mm & 5300 N.mm & 5750 N.mm \\
\hline 2. & 1 & 2 & 2 & 2 & 1600 N.mm & 2000 N.mm & 1800 N.mm \\
\hline 3. & 1 & 3 & 3 & 3 & 1700 N.mm & 1700 N.mm & 1700 N.mm \\
\hline 4. & 2 & 1 & 2 & 3 & 4900 N.mm & 6700 N.mm & 5800 N.mm \\
\hline 5. & 2 & 2 & 3 & 1 & 2300 N.mm & 4800 N.mm & 3550 N.mm \\
\hline 6. & 2 & 3 & 1 & 2 & 6600 N.mm & 6300 N.mm & 6450 N.mm \\
\hline 7. & 3 & 1 & 3 & 2 & 6400 N.mm & 5200 N.mm & 5800 N.mm \\
\hline 8. & 3 & 2 & 1 & 3 & 3300 N.mm & 5100 N.mm & 4200 N.mm \\
\hline 9. & 3 & 3 & 2 & 1 & 5000 N.mm & 4500 N.mm & 4750 N.mm \\
\hline
\end{tabular}

Keterangan

\begin{tabular}{|c|c|c|c|c|}
\hline No & Faktor Kualitas & $\mathbf{1}$ & $\mathbf{2}$ & $\mathbf{3}$ \\
\hline A & Temperatur peleburan & $940^{\circ}$ & $950^{\circ}$ & $970^{\circ}$ \\
\hline
\end{tabular}




\begin{tabular}{|c|l|c|c|c|}
\hline B & Temperatur cetakan & $60^{\circ}$ & $348^{\circ}$ & $530^{\circ}$ \\
\hline C & Jenis cetakan & Kuningan & Lilin & Besi \\
\hline D & Bahan tambah & $0 \%$ & $5 \%$ & $10 \%$ \\
\hline
\end{tabular}

\section{Data Pengujian dan Pembahasan}

Dari analisa perhitungan data-data yang di dapat dari hasil pengukuran dan perhitungan, maka kami dapatkan beberapa nilai sebagai tabel 3 diatas.

\section{KESIMPULAN DAN SARAN \\ Kesimpulan}

1. Matrik Orthogonal Array $L_{9}\left(3^{4}\right)$

2. Temperatur Peleburan $\left(940^{\circ} \mathrm{C}, 950^{\circ} \mathrm{C}, \& 970^{\circ} \mathrm{C}\right)$. Temperatur Cetakan (tidak dipanaskan $\&$ dipanaskan sampai dengan $60^{\circ} \mathrm{C}, 348^{\circ} \mathrm{C} \& 530^{\circ} \mathrm{C}$. Bahan Tambah (Tidak dengan bahan tambah \& Bahan tambah seng sebanyak (5\% \&10\%).TinggiLadel Sentuh).Penanganan Material (Tidakdibersihkan \& dibersihkan).Ukuran Material (Ukuran besar (real) \& dipotong kecil-kecil).

3. Dari data hasil perhitungan, maka dapat disimpulkan bahwa Momen Puntir tertinggi dari 9 kombinasi, 4 faktor dan 3 level yaitu 6450Nmm,. Adalah percobaan ke-6 dengan kombinasinya yaitu: Temperatur peleburan: $950{ }^{\circ} \mathrm{C}$ Temperatur cetakannya $530{ }^{\circ} \mathrm{C}$, Menggunakan Cetakan kuningan (Permanen) dan menggunakan bahan tambahnya 5\%

\section{Saran-Saran}

1. Melakukan proses produksi dengan kombinasi faktor yang lebih komplek dan maksimal yang berpengaruh pada peningkatan kekuatan puntir hasil coran

2. Menganalisa juga kualitas mekanis yang lainya misalnya kekuatan tarik keketasan maupun mikrostruktur

\section{DAFTAR PUSTAKA}

[1] Alexander, W, O, et . al, 1991, Essential Metallurgy for Engineers, Terjemahan Djaprie S. Dasar Metalurgi Untuk Rekayasawan, PT. Gramedia Pustaka Umum, Jakarta

[2] Bralla, I, James, G, 1986, Hand Book of Product Design for Manufacturing, Mc Graw Hill, New York

[3] Belavendram, N, 1995, Quality by Design, taguchi Technics for Industrial Exsperimentation, First Edition, Prentice Hall, London

[4] Dougles C. Montgomere, 1990, Introduction to Statistical Quality Control, John Wiley \& Sons Inc, Washingtong

[5] Erver H. S. 1988, Introduction to Physical Metallurgy, Second Edition, McGraw Hill, New York

[6] Gere, James, M dan Stephen P. Timoshenko, 1986, Mekanika Bahan, Erlangga, Jakarta

[7] Grant , Eugene L \& Leavenqorth Richard S, 1989, "Pengendalian Kualitas Statistik" Jilid 1 (Terjemahan), Edisi Keanam, Erlangga , Jakarta

[8] Heine, Richard, W, 1982, Principles of Metal Casting, Second Edition, Mc, Graw Hill, New York.

[9] Irwan Soejanto, 2001, Penentuan Faktor-faktor yang Berpegaruh Terhadap Kekerasan Blok Rem Kareta Api dengan Metode Taguchi, Surabaya, Tugas Akhir, Jurusan Teknik Industri, Institut Teknologi Sepuluh Nopember.l

[10] Jensein, Alfred dan Harry H. Chenowetrh, 1991, Kekuatan Bahan Terapan, Erlangga, Jakarta

[11] Julianingsih, Debora Anne Yang Aysia dan Donny Soegianto . 2004. Penentuan Komposisi Bahan Baku Optimal Produk Kecap X Dengan Metode Taguchi. Jurnal Teknik Industri , 6(2) : 121-133 
[12] Julianingsih dan Febrina Prasetyo.2003. Penentuan Kondisi Pengolatan dan Penyadian Bumbu Rawon Instan Bubuk Dengan Metode Taguchi, Jurnal Teknik Industri, 5(2) : 90-100

[13] Khoei, A.R, et al, 1999 , Design Optimisation of Aluminum Rrecylcling Process Using Taguchi Methode, $2^{\text {nd }}$ International Conference on intelligent Processing and Manufacturing of Material 513-518

[14] Kapakjian, S, 1989, manufacturing engineering adan Technology ,Addision Wesley Publish Company, Massachusettts

[15] Kücü Özkan, 2006, Application of Taguchi Methode in the Optimization of Dissolution of Ulexite in $\mathrm{NH}_{4} \mathrm{Cl}$ Solution, Korean J. Chem Eng, 23 (1), :21 -27

[16] Lawrence, Doyle, E, 1969, Manufacturing Processes and Material for Engineers, Prentice Hall Inc, Englewood Cliffs, New Jersey

[17] Montgomery, Douglan C, 1991, Design and Analysis of Exsperiment, Third Edition, John Wiley \& Sons, New York

[18] Nasier Wiedha Setyanto, 2002, Identifikasi Faktor-faktor yang Berpengaruh Terhadap Penyulingan Minyak Daun Cengkih Untuk Meningkatkan Hasil Produksi Dengan Pendekatan Metode Taguchi di Kecamatan Dongko Kaupaten Treggalek, Surabaya, Tesis Program Pasca Sarjana Teknik Industri, Institut Sepuluh Nopember.

[19] Palaniradja, K et , al, 2005, Optimization of Process Variables in Gas Carburizing Process, A Taguchi Study wity Experimental Investagation on SAE 8620 and AISI 3310 Steel, Turkish J, Eng, Env Sci, 29 : 279-284

[20] Ross, Philip J, 1996, Taguchi Tecniques for Quality Engineering, Second Edition, McGraw-Hill, New York

[21] Taguchi, Genichi, 1989, Quality Engineering in Production System, Mc Graw Hill Book Company, Singapure 